(c) 2009 Elsevier B.V. All rights reserved.

\title{
Effect of an herbivorous diet on energy balance of Litopenaeus vannamei at selected ontogenetic stages
}

\author{
Carlos Maldonado ${ }^{\mathrm{b}}$, Gerard Cuzon ${ }^{\mathrm{c}}$, Emilio Guzmán ${ }^{\mathrm{a}}$, Roberto Brito ${ }^{\mathrm{d}}$, Luis Soto ${ }^{\mathrm{e}}$, Leticia \\ Arena $^{\mathrm{a}}$ and Gabriela Gaxiola ${ }^{\mathrm{a},{ }^{*}}$
}

\footnotetext{
a Unidad Multidisciplinaria de Docencia e Investigación, Facultad de Ciencias UNAM, Sisal, Yucatán, México

${ }^{\text {b }}$ Posgrado de Ciencias del Mar y Limnología, UNAM, Mexico

${ }^{\mathrm{c}}$ Ifremer/COP, BP7004 Taravao, Tahiti, French Polynesia

d Universidad Autónoma del Carmen, Campeche, México

e Instituto de Ciencias del Mar y Limnología, UNAM, México
}

\begin{abstract}
*: Corresponding author : Gabriela Gaxiola, Tel./fax: +52 988912 0148, email address : mggc@hp.fciencias.unam.mx
\end{abstract}

\begin{abstract}
:
Herbivorous (20\% vegetable protein, $40 \%$ carbohydrate) and carnivorous diets (40\% marine animal protein, $20 \%$ carbohydrate) were experimentally tested to assess their effect on the energy balance and energetic substrates utilized by postlarvae (PL's /15 days) and juvenile shrimp (3-6 g) of Litopenaeus vannamei. Postlarval stage 60 ( $\mathrm{PL}_{60}$, early juveniles) shrimps fed $\mathrm{HeD}$ and $\mathrm{CaD}$ diets, then late juveniles (3-6 g) acclimated to the same diets were tested for their respective energy partitioning potential.

No significant differences $(p>0.05)$ on growth were obtained in early juveniles (mean final wet weight of $0.19 \mathrm{~g}$ ). However in late juvenile stages a significant difference $(p<0.05)$ in growth rate was observed. In terms of energy partitioning, both early and late juveniles seem to spend more energy in respiratory metabolism than in the elimination of excretion products. A change in feed composition based on quality protein sources induced some modifications on shrimp's activity measured by heat increment. Shrimps fed with an herbivorous diet showed a higher heat increment. Interestingly, the early stages of $L$. vannamei display a remarkable capacity to assimilate a plant protein-based and a high carbohydrate level diet. Such capacity with a stimulation of genes would lead to a good adaptation of juveniles receiving all-plant diets to sustain growth performances up to a marketable size. The implications of these findings for the shrimp farming feeding costs are briefly discussed.
\end{abstract}

Keywords: Shrimp; Protein sources; Metabolism; Juveniles; Energy 


\section{Introduction}

In early 70's, postlarvae (PL's) were already fed formulated compounded feeds with Penaeus californiensis (Colvin and Brand, 1977). Different diet compositions were shown to change metabolism of Litopenaeus setiferus PL's (Brito et al., 2000), Penaeus indicus and $P$. merguiensis early juveniles (Peñaflorida, 2002), and $L$. stylirostris juveniles (Rosas et al., 2000). Diet composition also affected energy budget in L. setiferus and L. vannamei PL's (Brito et al., 2004), L. vannamei PL's and early juveniles (Jiménez-Yan et al., 2006), and Fenneropenaeus chinensis juveniles (Huang et al., 2005).

One of the less studied aspects in crustacean bioenergetics was related with the calculation of daily digestible energy (DE) requirement. Generally, energy partitioning models gave ingestion rate and produced DE subtracting energy retained in faeces (non-digestible energy); from DE it was derived metabolizable (ME) and retained energy (RE) (Bureau et al., 2000).

The feed industry has recognized for many years that viable utilization of plant raw materials added in compound diets for the culture of aquatic organisms is a vital route for future development of aquaculture (Gatlin et al., 2007). Pond ecology would improved from use of feed ingredients, such as plant protein (Rowland et al., 2007) Moreover, Hari et al. (2006) shown that addition of carbohydrates to feed reduced total ammonia nitrogen in the water column and sediment in Penaeus monodom ponds, and that with a low (25\%) protein and carbohydrates diet, it is possible to obtain similar yield than with a high (40\%) protein without carbohydrates diet.

Energy partitioning obtained with $L$. vannamei PL's were not significantly affected by protein quality (animal versus plant protein, Jiménez-Yan et al., 2006). Then it was necessary to get a comprehensive approach on energy partitioning and substrate metabolism for $L$. vannamei Pl's and juveniles with a drastic change in feed composition, as well as their physiological consequences.

In this paper, considering the high omnivorous capacity reported for $L$. vannamei, it was tested a carnivorous animal diet (CaD) based in marine animal protein (40\%) and a herbivorous diet (HeD) with $17 \%$ plant protein and $40 \%$ carbohydrates (cbh) to evaluate $L$. vannamei performances. The objective was to analyze the effect of diet composition from 15 days old postlarvae until 3-6 g juveniles. Digestible energy (DE) estimation was obtained through oxygen consumption and nitrogen excretion of fasting and feeding shrimps. Energy channelled into growth was measured from carcass caloric content and daily growth rate. Metabolic substrates were determined according to O:N ratio variations. Additionally, it is emphasized on estimated values of DE requirement per day to define feeding rations and save resources in aquaculture.

\section{Material and Methods}

\subsection{Origin of the experimental animals}

Shrimps used in this study were obtained from one spawn produced in the UMDI-Sisal laboratory. Larvae were reared until PL's of 15 days old using Galveston system, and feeding schedule previously in operation in the laboratory (Gallardo et al., 2003). 


\subsection{Feeding trials}

Postlarvae of 15 days old $\left(\mathrm{Pl}_{15}\right)$ were transferred to $30 \mathrm{~L}$ plastic tanks, at a stocking density of 30 animals per tank. Temperature was maintained at $28 \pm 0.1^{\circ} \mathrm{C}$, salinity at $32.4 \pm 0.1 \%$, photoperiod $12 \mathrm{~h}$ light: $12 \mathrm{~h}$ dark. Tanks were supplied with constant aeration, which kept oxygen near saturation level $\left(6.3 \pm 0.04 \mathrm{mg} \mathrm{O}_{2} \mathrm{~L}^{-1}\right)$. Natural seawater was filtered through sand layer and then cartridges ( 5 and $\mathrm{m}$ ) plus UV sterilization. A 50\% daily water exchange was applied. Shrimps were fed two artificial feeds, an herbivorous diet (HeD) based on plant protein and carbohydrates, and carnivorous animal diet (CaD) based on marine animal protein (Table 1). Proximal analysis of the diets appeared in Table 2.

Animals were fed three times daily (0800, 1400, and 2000), and feed ratio adjusted every fortnight at $300 \%$ biomass from day 0 to 15 , followed by $200 \%$ biomass from day 15 to 30 , and $80 \%$ biomass from day 30 to 45 . Crumbles of $250-350 \mathrm{~m}$ were used at the beginning of the experiment, increasing size until $800-1000 \mathrm{~m}$ at end. After 45 days $\mathrm{PI}_{60}$ (thereafter refered as early juveniles) were sampled. Other group of shrimps was transferred to $400 \mathrm{~L}$ tanks and fed with the same diets (at $10 \%$ of biomass as daily ration) during six weeks, then sampled for weight, and after 45 days, new samples were obtained for physiological measurements (thereafter refered as late juveniles).

The experimental feeds were prepared in the laboratory by thoroughly mixing dry ingredients with oil and then adding water until firm dough was obtained. The dough was passed through a meat-mincer equipped with a $2 \mathrm{~mm}$ die, and resulting strands were air-dried at $60^{\circ} \mathrm{C}$ overnight. After drying, pellets were broken, sieved to a convenient size and stored at $-40^{\circ} \mathrm{C}$ until use.

\subsection{Energy partitioning}

The amount of energy channeled into growth $(R E)$, maintenance $\left(H_{e} E\right)$, excretion (UE+ZE) for each treatment was obtained during the experiment through several measurements. Individual wet and dry weight was measured using a Cahn model C-33 microbalance with $0.001 \mathrm{mg}$ accuracy. Initial wet and dry weight of shrimp was determined from samples of 50 individuals. Shrimps were washed with distilled water and oven-dried at $60^{\circ} \mathrm{C}$ for $24 \mathrm{~h}$. The same procedure was used to obtain final weight of animals in each treatment. Initial and final energy content of shrimps from each treatment were obtained by means of an adiabatic bomb calorimeter (Parr), previously calibrated with benzoic acid. Data on individual dry weight gains in $\mathrm{mg}^{-1}$ day ${ }^{-1}$ were transformed into energy with corresponding units to express values of $R E$ in $\mathrm{J} \mathrm{d}^{-1}$ shrimp ${ }^{-1}$.

Oxygen consumption and ammonia excretion were measured individually in 10 early juvenile for each diet treatment using $100 \mathrm{~mL}$ respirometric chambers. For late juveniles (10 animals for treatment) chambers of $250 \mathrm{~mL}$ were set up. A flow through respirometer system in a closed system was used according to Rosas et al. (1998). Oxygen tension in water at the entrance and exit of respirometric chambers was measured using an oxygen electrode (YSI 50B). Oxygen consumption was first determined (0800) in 24 hours fasting shrimps, which were previously acclimated during 14 hours to the respirometric chambers. Then the animals were fed the corresponding diet for each treatment and oxygen consumption was measured every one hour from 0900 until 1400 in early juveniles and from 0900 until 1500 in late juveniles. At the same time water samples of the entrance and exit of the chambers were stored in Ependorff tubes with sublimated iodine and preserved frozen until analysis for ammonia. Ammonia concentration in samples was always determined less than $12 \mathrm{~h}$ after sampling, following the method proposed by Strickland and Parsons 
(1972), adapted by Hernández-López and Vargas-Albores (2003) for small water samples. Only shrimps fed in the chamber were used for the analyses.

Respiration $\left(\mathrm{mgO}_{2} \mathrm{~h}^{-1}\right.$ shrimp $\left.{ }^{-1}\right)$ was estimated as basal $\left(\mathrm{H}_{\mathrm{e}} \mathrm{E}\right)+$ heat increment of feeding $\left(\mathrm{H}_{\mathrm{i}} \mathrm{E}\right)$, where $\mathrm{H}_{\mathrm{e}} \mathrm{E}$ (routine metabolism) was the oxygen consumption of unfed animal and $\mathrm{H}_{\mathrm{i}} \mathrm{E}$ was the value of the peak of heat increment after feeding. These values were converted to energy by the coefficient $14.3 \mathrm{~J} \mathrm{mg}^{-1} \mathrm{O}_{2}$ (Lucas, 1996). $\mathrm{He}_{\mathrm{e}} \mathrm{E}(\mathrm{J}$ $\mathrm{d}^{-1}$ shrimp $\left.{ }^{-1}\right)$ was estimated considering day time where shrimps were not fed, $\mathrm{H}_{\mathrm{i}} \mathrm{E}\left(\mathrm{J} \mathrm{d}^{-1}\right.$ shrimp $^{-1}$ ) was measured by the peak of oxygen consumption after feeding and number of rations $(n=3)$ fed to shrimps per day. Similarly, excretion was estimated as routine nitrogen excretion (UE+ZE) plus post-alimentary nitrogen excretion (PANE) and these values were converted to energy by the coefficient $20.5 \mathrm{~J} \mathrm{mg}^{-1} \mathrm{~N}-\mathrm{NH}_{3}$ (Lucas, 1996). Excretion $\left(\mathrm{J} \mathrm{d}^{-1}\right.$ shrimp $\left.{ }^{-1}\right)$ was estimated taken into consideration the same factors as in respiration.

Digestible energy (DE) for shrimps was calculated as:

$\mathrm{DE}=\mathrm{RE}+\left(\mathrm{H}_{\mathrm{e}} \mathrm{E}+\mathrm{H}_{\mathrm{i}} \mathrm{E}\right)+(\mathrm{UE}+\mathrm{ZE})$

where RE is the energy channelled into growth, and came from the conversion of daily growth rate in energy values using the carcass caloric content; $\left(\mathrm{H}_{\mathrm{e}} \mathrm{E}+\mathrm{H}_{\mathrm{i}} \mathrm{E}\right)$ is the energy lost in respiration, (UE+ZE) the energy lost in excretion.

The proportion of digestible energy (DE) invested into growth (RE/DE) was calculated.

\subsection{Metabolic substrate}

$\mathrm{O}: \mathrm{N}$ atomic ratio was calculated transforming oxygen consumption and ammonia excretion of fast and fed shrimps data to gAt. Feeding O:N ratio were estimated with maximum oxygen consumption and ammonia excretion after shrimps feeding. O:N values from 3-16 correspond to pure protein substrate metabolism; between 50-60 for a mix of protein plus lipids; above this value represents the mix of lipids plus carbohydrates (Mayzaud and Conover, 1988).

\subsection{Statistical analysis}

To test differences between initial weight of experimental shrimps and the effect of diets on survival, final weight, growth rate, digestible energy, as well as on the energy channelled into growth, respiration and excretion, data were contrasted by StudentWednesday, February 3, 2010s t analysis. Survival data were transformed to arcsin prior to apply the test.

\section{Results}

\subsection{Zootechnical parameters}

Survival of early juveniles were significantly affected by diets, shrimps fed CaD presented a lower value $(73.3 \%)$ than those fed HeD with $91.7 \%(p<0.05)$. In late juveniles diets had not effect on survival (mean value 95.8\%, $p>0.05$ ). Final wet weights were similar in early juveniles fed both diets $(p>0.05)$, but in late juveniles HeD affected negatively shrimp growth $(p<0.05)$ with lower final weight $(3.3 \mathrm{~g})$, than those fed $\mathrm{CaD}$ that reached $6.09 \mathrm{~g}$ (Table 3). 


\subsection{Oxygen consumption}

During fasting, early juveniles from CaD treatment respired at a rate of $1.35 \mathrm{mgO}_{2} \mathrm{~h}^{-}$ ${ }^{1}$ shrimp $^{-1}$, similar value was obteined in those fed $\mathrm{HeD}\left(1.14 \mathrm{mgO}_{2} \mathrm{~h}^{-1}\right.$ shrimp $\left.{ }^{-1}\right)($ Fig. $1 \mathrm{a}$ and $b$ ). Feeding increased oxygen consumption in both treatments, in early juveniles from $\mathrm{CaD}$, heat increment reach a peak one hour after feeding $\left(2.91 \mathrm{mgO}_{2} \mathrm{~h}^{-1}\right.$ shrimp $\left.{ }^{-1}\right)$, and returned to fasting levels in the next hour, whereas in those fed HeD oxygen consumption paullatinaly rose until three hours after feeding with a peak in $3.28 \mathrm{mgO}_{2} \mathrm{~h}^{-}$ ${ }^{1}$ shrimp ${ }^{-1}$.

Late juveniles from $\mathrm{CaD}$ treatment consumed $3.9 \mathrm{mgO}_{2} \mathrm{~h}^{-1}$ shrimp ${ }^{-1}$ during fasting, while in fasting animals from HeD treatment the oxygen consumption was $1.6 \mathrm{mgO}_{2} \mathrm{~h}^{-}$ ${ }^{1}$ shrimp $^{-1}$ (Fig. 1c and d). After feeding, oxygen consumption rose until $5.4 \mathrm{mgO}_{2} \mathrm{~h}^{-}$ ${ }^{1}$ shrimp $^{-1}$ in CaD fed shrimps and up to 3.5 mgO $_{2} \mathrm{~h}^{-1}$ shrimp ${ }^{-1}$ in $\mathrm{HeD}$ fed shrimps. Both treatments shown a similar pattern with a peak in heat increment two hours after feeding, but in $\mathrm{CaD}$, oxygen consumption returned to basal level four hours after feeding while HeD fed shrimps required seven hours to reach basal level.

\subsection{Nitrogen excretion}

Ammonia excretion in early juveniles from $\mathrm{CaD}$ treatment (Fig. 2a) was $0.006 \mathrm{mg} \mathrm{N}$ $\mathrm{NH}_{3} \mathrm{~h}^{-1}$ shrimp ${ }^{-1}$ in fasting shrimps, with a peak $\left(0.02 \mathrm{mg} \mathrm{N}^{-N_{3}} \mathrm{~h}^{-1}\right.$ shrimp $\left.{ }^{-1}\right)$ four hours

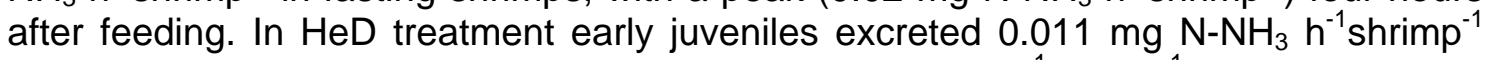

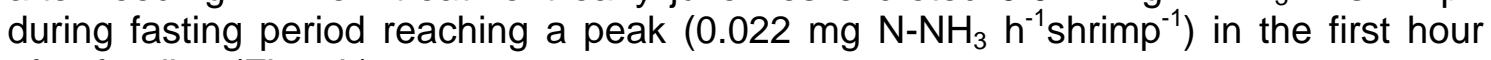
after feeding (Fig. 2b).

Late juveniles from both treatments (Fig. $2 \mathrm{c}$ and d) shown similar excretion values in

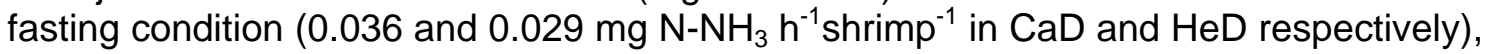
shrimps from $\mathrm{CaD}$ reach a peak in ammonia excretion four hours after feeding $(0.161$ mg N-NH $\mathrm{h}^{-1}$ shrimp ${ }^{-1}$ ), while HeD shrimps had a peak in ammonia excretion only two hours after the meal $\left(0.105 \mathrm{mg} \mathrm{N}^{-} \mathrm{NH}_{3} \mathrm{~h}^{-1}\right.$ shrimp $\left.{ }^{-1}\right)$. Post-alimentary peak in ammonia excretion represent an increment of $440 \%$ respect to basal leves in $\mathrm{CaD}$ animals, whereas in HeD shrimps the highest value in excretion represent $350 \%$ of basal level.

\subsection{Energy partitioning}

In early juveniles retained energy showed similar values $(p<0.05)$ in both treatments with 59.4 and $76.9 \mathrm{~J}_{\text {shrimp }}{ }^{-1}$ day $^{-1}$ for $\mathrm{CaD}$ and HeD respectively (Table 4). Energy partitioning showed significant differences associated with digestion process of the different diets, energy spent in post-alimentary excretion (PANE) was significantly higher when animals fed $\mathrm{CaD}$ (2.25 versus $0.61 \mathrm{~J} \mathrm{shrimp}^{-1}$ day $^{-1}$ in HeD), meanwhile energy corresponding to heat increment $\left(\mathrm{H}_{\mathrm{i}} \mathrm{E}\right)$ was significantly higher in $\mathrm{HeD}(164.4 \mathrm{~J}$ shrimp ${ }^{-1}$ day $^{-1}$ ) than in CaD shrimps $\left(67.1 \mathrm{~J} \mathrm{shrimp}^{-1}\right.$ day $\left.^{-1}\right)$.

Contrary to early juveniles, in late juveniles recovered energy was significantly higher in CaD treatment (329.4 $\mathrm{J}_{\text {shrimp }}{ }^{-1}$ day $^{-1}$ versus only $131.8 \mathrm{~J} \mathrm{shrimp}^{-1}$ day $^{-1}$ in HeD shrimps). Here again, energy channeled to $\mathrm{H}_{\mathrm{i}} \mathrm{E}$ was significantly higher in HeD shrimps $\left(284.8 \mathrm{~J} \mathrm{shrimp}^{-1}\right.$ day $^{-1}$ ) than in animals from CaD treatment $\left(128.4 \mathrm{~J} \mathrm{shrimp}^{-1}\right.$ day $\left.^{-1}\right)$, but energy associated with PANE was similar in both treatments (Table 4). The proportion of digestible energy (DE) invested into growth (RE/DE) was similar in early juveniles from both diets, however in late juveniles this proportion was higher in $\mathrm{CaD}$ than in HeD fed animals. 


\subsection{Metabolic substrate}

The metabolic substrate was estimated from the $\mathrm{O}: \mathrm{N}$ ratio in early and late juveniles during fast and fed status (Table 5). Substrate metabolism showed differences during starvation in early juveniles, with a mixture of lipid plus cbh en $\mathrm{CaD}$ animals and a mixture of protein plus lipids in HeD shrimps. In both treatments a mixture of lipids and cbh is utilized as metabolic substrate in fed animals. Late juveniles from CaD treatment used lipids plus cbh as substrate during fasting period, same as in early juveniles, but in HeD protein had greater importance as substrate during starvation. In both treatments later juveniles changed their substrate metabolism to protein and lipids when feeding. In general, later juveniles showed a higher use of protein as metabolic substrate than early juveniles.

\section{Discussion}

Shrimp during its life cycle in nature from larvae to PL's migrate from oceanic to brackish waters in mangrove areas. There is a drastic change in feeding habits with presence of plant debris, benthic organisms, bacteria and also due to its herbivorous tendency and a trypsin activity that is high compared to carnivorous species (Lemos and Rodriguez, 1998). Moreover, PL's will probably show a remarkable flexibility to utilize protein (Brito et al., 2001) as well as cbh sources to prepare for juvenile stages (Jiménez-Yan et al., 2006); its demand in energy from all food sources to sustain a rapid growth rate is obviously high. In $L$. vannamei juveniles, reared in commercial ponds under semi-intensive conditions, Gamboa-Delgado et al. (2003) observed that plant matter contributed above $30 \%$ of stomach content and detritus represented up to $58 \%$, meanwhile artificial feed contributed in less than $20 \%$, showing the capability of this species to used vegetal food, and suggested an ontogenetic adaptation of the enzymatic activity with a decrease in total protease and an increase in lipase and amylase activities as shrimp growth.

Variations on oxygen consumption and ammonia excretion according to the diet composition were observed in this study. The main difference between treatments was related to higher lapse needed for HeD fed animals for return oxygen consumption to basal levels after feeding. Apparent heat increment has been related with dietary protein levels in different species of shrimps PL's (Rosas et al., 1996), as well as in $L$. vannamei early juveniles (Jiménez-Yan et al., 2006), but these authors used diets with protein levels higher than $40 \% \mathrm{CP}$. On line with this study, Rosas et al. (2001) found that in L. vannamei juveniles a diet with high cbh level produced a heat increment $244 \%$ higher than the obtained when shrimps fed with a diet containing low cbh, therefore, in this case the pattern in heat increment seems not to be related with protein content but with the cbh level in the diet. $\mathrm{H}_{\mathrm{i}} \mathrm{E}$ varied according to the nature of protein source as well. Already with Marsupenaeus japonicus juveniles, soy-protein concentrate produced a larger variation in $\mathrm{H}_{\mathrm{i}} \mathrm{E}$ than on crab protein (Teshima, 1998) and in a first approximation it could be higher with vegetable protein than with animal protein diet. $\mathrm{H}_{\mathrm{e}} \mathrm{E}$ did not vary significantly either in early or in late juveniles fed both diets. By and large, RE ( $\mathrm{J}_{\text {shrimp }}{ }^{-1}$ day $^{-1}$ ) did not vary significantly under dietary alteration in early juveniles. It meant that the partition of energy did not differ from one diet to another at this stage.

Jiang et al. (2000) indicated that L. vannamei is ammonotelic, with ammonia accounting for up to $84 \%$ of total nitrogen excretion. In this sense Burford and Williams (2001) stated that in P. monodom the main source of dissolved nitrogen is ammonia excreted from the gills, they also found that excretion rate was three times higher after feeding than that for starved animals. In this study, ammonia excretion after feeding 
presented higher values in $\mathrm{CaD}$ (440\% respect to basal levels) than in $\mathrm{HeD}(350 \%$ respect to basal levels), which could be related to higher protein contents in $\mathrm{CaD}$ $(40 \% \mathrm{CP})$ than in HeD (20\%), but also with cbh levels in diet. When analyzing the effect of cbh upon excretion, Rosas et al. (2001) found that ammonia excretion as a percentage of fasting rates was higher in shrimps fed low cbh diet than the obtained in animals fed a diet with high cbh level. In this sense Hari et al. (2006) showed that addition of cbh to the diet reduced total ammonia nitrogen in $P$. monodon.

From energy point of view, the only difference in excretion found in this study was related to higher energy expended in PANE when early juveniles fed CaD. Nevertheless excretion represent a minor item in the shrimp budget, here the proportion of excretion to DE was less than $2 \%$ in all cases, so the contribution of excretion on energy balance was negligible.

On line with this study, L. vannamei that fed animal or plant protein sources during the PL's phase provided consistent results in terms of energy partitioning with equal amount for RE (Jiménez-Yan et al., 2006). RE expressed in \%DE was similar in early juveniles fed respectively on $\mathrm{CaD}$ or $\mathrm{HeD}$, but in late juveniles a greater amount of $\mathrm{DE}$ was channelled into $\mathrm{RE}$ when fed on $\mathrm{CaD} . \mathrm{H}_{\mathrm{i}} \mathrm{E}$ presented some variations and protein source tended to decrease $\mathrm{H}_{\mathrm{E}} \mathrm{E}$ with $\mathrm{CaD}$ compared to $\mathrm{HeD}$. By and large, animal or plant protein sources had low incidence on PL's RE in a range of $26-27 \%$ respectively even though level of variability was important (Jiménez-Yan et al., 2006).

$\mathrm{O}: \mathrm{N}$ ratio brought additional information on metabolic substrate related to feed composition. O: $\mathrm{N}$ was quite high at 160-164 in fed early juveniles from CaD or HeD; it indicated lipid and cbh as energy substrates (Mayzaud and Conover, 1988). In the same way in fed late juveniles from either $\mathrm{CaD}$ or $\mathrm{HeD}$, the O:N ratio at 34 was for an utilization of a mix protein plus lipid. It emphasized the role of protein as main energy substrate. In $L$. stylirostris juveniles, increased levels of dietary protein produced a decrease in O:N ratio (Gauquelin et al., 2007). In the present study, due to feeding background of juveniles, metabolism was driven on same substrate indifferently of actual diet composition. This trend signed a nutrition status that was more omnivory than herbivory as described previously with zooplankton (Bougis, 1974; McTigue and Zimmerman, 1991). The use of protein as source of energy is well documented in shrimp (Dall and Smith, 1986). The effect of dietary protein levels and protein/energy ratio on O:N has also been reported. Rosas et al. (2001) found that when shrimps were fed a low cbh diet used proteins as source of energy at fasting or feeding status, but when animals fed a high cbh diet, metabolic substrate during fasting are mainly protein and changed to a mixed substrate when feeding. In L. setiferus juveniles O:N changed in relation to dietary protein level, with a mixture of protein and lipids when shrimp fed a $30 \%$ CP diet (Taboada et al., 1998). Also in L. vannamei juveniles fed animal or plant protein diets, O:N indicated an energy derived mainly from protein and lipid (JiménezYan et al., 2006).

A replacement of protein with cbh reduced weight gain in late juveniles, however in early juveniles produced similar values. Addition of cbh to a low protein diet (25\% CP) give similar yield and improved protein efficiency ratio when compared with a high protein diet (40\% CP) without cbh in $\mathrm{Pl}_{20}$ P. monodom (Hari et al., 2006). Eventually, it was shown a sparing-effect of cbh as energy substrate preserving amino acid (aa) for protein synthesis but all aspects of feed utilization should be considered such as intake, DE, (UE+ZE), $H_{i} E, H_{e} E$ and RE. However, some elements of the budget were difficult to address such as feed intake. $\mathrm{H}_{\mathrm{i}} \mathrm{E}$ varied according to the nature of protein source as well. Already with $M$. japonicus juveniles, soy-protein concentrate produced a larger variation in $\mathrm{H}_{\mathrm{i}} \mathrm{E}$ than on crab protein (Teshima, 1995) and in a first approximation; it could be higher with plant protein than animal protein diet. $\mathrm{H}_{\mathrm{e}} \mathrm{E}$ did not vary significantly. RE (J shrimp ${ }^{-1}$ day $^{-1}$ ) did not vary significantly under dietary alteration in early juveniles, but was increased in late juveniles fed CaD. 
The category of plant protein sources such as Spirulina, wheat gluten or soyconcentrate seemed to bring a reasonable potential for partial or total replacement of fish meal I $\mathrm{n}$ diets. Replacement of $50 \%$ fish meal with soybean meal enhanced retention of protein due to a decline in protein degradation in $L$. vannamei juveniles (Mente et al., 2002). Moreover, evidence appeared of a cbh sparing-effect on dietary protein with wild $L$. vannamei juveniles raised under laboratory conditions (Arena et al., 2003). L. vannamei early juveniles helped to verify this concept.

There was a conflicting situation between a protein-rich feed provided more RE than low protein diet. In a protein-rich diet such as $\mathrm{CaD}$, aa that were not used for protein synthesis were more efficiently utilized as energy source than glucose. On the other hand, a high-cbh based diet (mainly starch) such as HeD provided glucose that could limit deamination and divert more aa to protein synthesis. Up to now, the most efficient pathway has been described in the first option, i.e. more protein, more weight gain. But this case was described mainly with carnivorous species such as $L$. stylirostris late juveniles (Gauquelin, et al, 2007). The second option, a pathway with cbh-sparing effect on dietary protein could be more suited for a species such as $L$. vannamei for which a low muscle protein turnover was measured (Mente et al., 1997). Prerequisites could be (i) enough amylase isoformes, i.e. enough polymorphism given by amylase genes allelic frequency on the population, (ii) a stimulation of amylase genes in early stages of development by feeding with plant sources, and (iii) a well-balanced aa profile in order to contribute to make available simultaneously all essential aa in free pool for efficient on-site muscle protein synthesis.

A mixture of marine protein sources benefited shrimps because of an excellent aa profile and a limiting factor bearing on tryptophan. Are there some essential aa missing in plant protein? The improbability of lysine and methionine being limiting aa in practical rations was discussed previously. The use of uncoated crystalline aa was proved inefficient in fish (Cowey, 1994) or shrimp as well (Deshimaru and Kuroki, 1975) and then it was preferred to use the formulated diets as such taking into account a frequent supply of minute amount of feed that probably reduced the impact of a limiting factor. Coated aa would help solve the problem as well.

A mixture of digestible ingredients (Spirulina, wheat gluten, and soy-concentrate) gave such aa profile in spite of a lysine deficit in relation to the presence of plant protein sources. Complementation with fish meal and $\mathrm{CPSP}^{80}$ helped make adjustment on aa profile. On top of that, feed distribution was fractionated during the day rendering a possible limiting factor less critical regarding any imbalance of indispensable amino acids for protein synthesis. All the prerequisites described above were found achievable through this study even though confirmation and adjustments in formulations still remain to be done. According to Mente et al. (2002), it appears that in shrimps there is a little scope for recycling of essential amino acids if these become limiting in the diet. These authors suggested that high growth rates seem to involve a reduction in the turnover of proteins, a lower protein turnover may conserve energy for growth (or other processes), as protein turnover is responsible for a large fraction of the energy budget (Conceição, 1997).

In this study early juveniles utilized indifferently and efficiently a mix of animal protein or another diet with plant protein. This flexibility is shown not so in terms of protein balance because of similar aa profile rather than on energy partitioning, animals derived equal $D E$ amount to $R E$ in spite of difference in excretion. Those aspects evidenced an omnivory-herbivory trend found previously with this species. The ability of L. vannamei to spare protein with an upper level of digestible starch appeared already in a previous work on juveniles captured from the wild (Arena et al., 2003).

Replacing fish meal by plant protein, maintaining low CP percentage increasing cbh levels, multiple meals, and a good attractiveness of the diet, should guide for feeds in perspective of sustainable farming nursery production. Level of animal protein 
replacement by plant protein from a culture viewpoint is verified with an incidence on metabolism and energy partitioning. Similar performances on early juveniles with $\mathrm{CaD}$ or HeD showed a certain potential for adaptation to plant protein with a lot of starch.

The course of the project aimed at demonstrate a better adaptation to a cbh-rich diet based on plant protein sources given as early as possible in the life cycle. Such preparation of animals with a stimulation of genes would lead to a good adaptation of juveniles receiving all-plant diets to sustain growth performances up to a marketable size. Such premises examined not only performances, but physiological aspects with energy partitioning, body reserves and tissue metabolism to give evidence of proper activation of key enzymes under diet variations, set the ground to further selection program. L. vannamei represent a good model to study such potentialities while using these and previous data accumulated at all stages of its life cycle.

\section{Acknowledgements}

We thanks for the financial support to UNAM IN 216406 and CONACyT 49406/24750 and the technical support of Biol. Gabriela Palomino in live food for larvae production; Ing Miguel Arévalo for nauplii production; Ing. Adriana Paredes for larval rearing; Biol Manuel Valenzuela, for broodstock management and Biol. Gabriel Taboada for artificial feed elaboration.

\section{References}

Arena, L., Cuzon, G., Pascual, C., Gaxiola, G., Soyez, C., Van Wormhoudt, A., Rosas, C., 2003. Physiological and genetic variations in domesticated and wild populations of Litopenaeus vannamei fed with different carbohydrates levels. J. Shellfish Res. 22(1), 269-279.

Bougis, R., 1974. Ecologie du plancton marin. II le zooplancton. Collection écologie. Masson et Cie, Paris. 200pp.

Brito, R., Chimal, M.E., Gaxiola, G., Rosas, C., 2000. Growth, metabolic rate, and digestive enzyme activity in the white shrimp Litopenaeus setiferus early postlarvae fed different diets. J. Exp. Mar. Biol. Ecol. 255, 21-36.

Brito, R., Rosas, C., Chimal, M.E., Gaxiola, G., 2001. Effect of different diets and digestive enzyme activity in Litopenaeus vannamei (Boone, 1931) early post-larvae. Aqua. Res. 32, 257-266.

Brito, R., Chimal, M.E., Gelabert, R., Gaxiola, G., Rosas, C., 2004. Effect of artificial and natural diets on energy allocation in Litopenaeus setiferus (Linnaeus, 1767) and Litopenaeus vannamei (Boone, 1931) early postlarvae. Aquaculture 237, 517-531.

Bureau, B.P., Azevedo, P.A., Tapia-Salazar, M., Cuzon, G., 2000. Pattern and cost of growth and nutrient deposition in fish and shrimp: Potential implications and applications. In: Cruz -Suárez, L.E., Ricque-Marie, D., Tapia-Salazar, M., OlveraNovoa, M.A., Civera-Cerecedo, R., (Eds.), Avances en Nutrición Acuícola V. Memorias del V Simposium Internacional de Nutrición Acuícola, 19-22 Noviembre 2000, Mérida, México, 111-140. 
Burford, M.A., Williams, K.C., 2001. The fate of nitrogenous waste from shrimp feeding. Aquaculture 198, 79-93.

Colvin, L.V., Brand, C.W., 1977. The protein requirement of penaeid shrimp at various life-cycle stages in controlled environment systems. In: Charleston, SC (Ed.), Proceeding 8th Annual Meeting WMS, San José, Costa Rica, Publ. LSU. Div. Cont. Edu., Baton Rouge, LA (USA), 821-840.

Conceição, L.E.C., Van Der Meeren, T., Verreth, J.A.J., Evjen, M.S., Houlihan, D.F., Fyhn, H.J., 1997b. Amino acid metabolism and protein turnover in larval turbot (Scophthalmus maximus) fed natural zooplankton or Artemia. Mar. Biol. 129, 255-265.

Cowey, C.B., 1994. Amino acid requirements of fish: A critical appraisal of present values. Aquaculture 124, 1-11.

Dall, W., Smith, D.M., 1986. Oxygen consumption and ammonia-N excretion in fed and starved tiger prawns Penaeus esculentus Haswell. Aquaculture 55, 23-33.

Deshimaru, O., Kuroki, K., 1975. Studies on a purified diet for prawn-IV: evaluation of protein, free amino acids and their mixture as a nitrogen source. Bull. Jap. Soc. Sci. Fish. 41, 101-103.

Gallardo, P., Martínez, G., Pedroza-Islas, R., Cuzon, G., Gaxiola, G., 2003. Effect of Artemia nauplii substitution by artificial feed containing krill hydrolysate on ingestion rate, oxygen consumption and energy budget of the mysis of Litopenaeus vannamei (Boone, 1931). Nauplius 11(2), 69-81.

Gamboa-Delgado, J., Molina-Poveda, C., Cahu, C., 2003. Digestive enzyme activity and food ingesta in juvenile shrimp Litopenaeus vannamei (Boone, 1931) as a function of body weight. Aquacult. Res. 34 (15), 1403-1411.

Gatlin III, D.M., Barrows, F.T., Brown, P., Dabrowski, K., Gaylord, T.G., Hardy, R.W., Herman, E., Hu, G., Krogdahl, Å., Nelson, R., Overturf, K., Rust, M., Sealey, W., Skonberg, D., Souza, E.J., Stone, D., Wilson, R., Wurtele, E., 2007. Expanding the utilization of sustainable plant products in aquafeeds: a review. Aquac. Res. 38, 551579.

Gauquelin, F., Cuzon, G., Cochard, J.C., Gaxiola, G., Rosas, C., Bureau, D.P., 2007. Effect of dietary protein level on growth and energy utilization by Litopenaeus stylirostris under laboratory conditions. Aquaculture 271, 439-448.

Hari, B., Madhusoodana Kurup, B., Varghese, J.T., Schrama, J.W., Verdegem, M.C.J., 2006. The effect of carbohydrate addition on water quality and the nitrogen budget in extensive shrimp culture systems. Aquaculture 252, 248-263.

Hernández-López, J., Vargas-Albores, F., 2003. A microplate technique to quantify nutrients $\left(\mathrm{NO}_{2}, \mathrm{NO}_{3}, \mathrm{NH}_{4}{ }^{+}\right.$and $\left.\mathrm{PO}_{4}{ }^{3}\right)$ in seawater. Aquac. Res. 34, 1201-1204.

Huang, G., Dong, S., Wang, F., 2005. Growth, energy allocation, and biochemical composition of the body of Chinese shrimp, Fenneropenaeus chinensis, fed different diets. Crustaceana 78 (2), 141-162. 
Jiang, D., Lawrence, A.L., Neill, H.W., Gong, H., 2000. Effects of temperature and salinity on nitrogenous excretion by Litopenaeus vannamei juveniles. J. Exp. Mar. Biol. Ecol. 253, 193-209.

Jiménez-Yan, L., Brito, A., Cuzon, G., Gaxiola, G., García, T., Taboada, G., Soto, L., Brito, R., 2006. Energy balance of Litopenaeus vannamei postlarvae fed on animal or plant protein based compounded feeds. Aquaculture 207, 337-345.

Lemos, D., Rodriguez, A., 1998. Nutritional effect on body composition and trypsin activity of Penaeus japonicus during early postlarva development. Aquaculture 160, 103-116.

Lucas, A., 1996. Bioenergetics of Aquatic Animals. Taylor and Francis, London, 169 pp.

Mayzaud, P., Conover, R.J., 1988. O:N atomic ratio as a tool to describe zooplankton metabolism. Mar. Ecol. Prog. Ser. 45, 289-302.

McTigue, T.A., Zimmerman, R.J., 1991. Carnivory vs herbivory in juveniles Penaeus setiferus (Linnaeus) and Penaeus aztecus (Ives). J. Exp. Mar. Biol. Ecol. 151, 1-6.

Mente, E., Houlihan, D.F., Sorgeloos, P., 1997. Growth and protein metabolism in Crustacea: low turnover in tropical shrimps? Proceedings Island and Tropical Aqua., Martinique, Les Trois Islets, mai 1997, 4-9.

Mente, E., Coutteau, P., Houlihan, D., Davidson, I., Sorgeloos, P., 2002. Protein turnover, amino acid profile and amino acid flux in juvenile shrimp Litopenaeus vannamei: effects of dietary protein source. J. Exp. Biol. 205, 3107-3122.

Peñaflorida, V.D., 2002. Evaluation of plant proteins as partial replacement for animal proteins in diets for Penaeus indicus and $P$. merguiensis juveniles. Israeli $\mathrm{J}$. Aquaculture/Bamidgeh 54(3), 116-124.

Rosas, C., Cuzon, G., Gaxiola, G., Arena, L., Lemaire, P., Soyez, C., van Wormhoudt, A., 2000. Influence of dietary carbohydrate on the metabolism of juvenile Litopenaeus stylirostris. J. Exp. Mar. Biol. Ecol. 249, 181-198.

Rosas, C., Cuzon, G., Gaxiola, G., Le Priol, Y., Pascual, C., Rossignyol, J., Contreras, F., Sánchez, A., Van Wormhoudt, A., 2001. Metabolism and growth of juveniles of Litopenaeus vannamei: effect of salinity and dietary carbohydrate levels. J. Exp. Mar. Biol. Ecol. 259, 1-22.

Rosas, C., Martínez, E., Gaxiola, G., Brito, R., Díaz, E., Soto, L.A., 1998. Effect of disolved oxygen on the energy balance and survival of Penaeus setiferus juveniles. Mar. Ecol. Prog. Ser. 174, 67-75.

Rosas, C., Sánchez, A., Díaz, E., Soto, L.A., Gaxiola, G., Brito, R., 1996. Effect of dietary protein level on apparent heat increment and post-prandial nitrogen excretion of Penaeus setiferus, $P$. schmitti, $P$. duorarum and $P$ notialis postlarvae. J. World Aqua. Soc. 27, 92-102.

Rowland, S.J., Allan, G.L., Mifsud, C., Read, P.A., Glendenning, D., Ingram, B.A., 2007. Effects of diets with different plant proteins on the performance of silver perch 
(Bidyanus bidyanus Mitchell) and on water quality in earthen ponds. Aquac. Res. 38, 748-756.

Strickland, J.D., Parsons, T.R., 1972. A Practical Handbook of Seawater Analysis. Fish. Res. Bd. Can. 167, 1-311.

Taboada, G., Gaxiola, G., García, T., Pedroza, R., Sánchez, A., Soto, L.A., Rosas, C., 1998. Oxygen consumption and ammonia-N excretion related to protein requirements for growth of white shrimp Penaeus setiferus. Aquac. Res. 29, 1-11.

Teshima, S. 1998. Nutrition of Penaeus japonicus , Rev. Fish.Sci 6(1-2), 97-111. 
Table 1. Diets composition $\left(\mathrm{g} \mathrm{kg}^{-1}\right)$ for early and late juveniles.

\begin{tabular}{|c|c|c|}
\hline & $\mathrm{CaD}$ & HeD \\
\hline${ }^{(1)}$ squid meal ${ }^{72}$ & 200 & - \\
\hline${ }^{(1)}$ fishmeal $^{65}$ & 190 & - \\
\hline${ }^{(2)} \mathrm{CPSP}^{70}$ & 40 & 45 \\
\hline dry whey ${ }^{80}$ & 120 & - \\
\hline${ }^{(3)}$ wheat gluten ${ }^{80}$ & - & 70 \\
\hline${ }^{(2)}$ soybean concentrate ${ }^{60}$ & - & 150 \\
\hline Spirulina $^{72}$ & - & 45 \\
\hline (3) wheat starch & 200 & 400 \\
\hline cod liver oil & 37 & 60 \\
\hline soy lecithin & 20 & 20 \\
\hline cholesterol & 5 & 5 \\
\hline (4) vitamin and mineral premix & 10 & 10 \\
\hline (4) vitamin Stay-C-35\% & 4.5 & 4.5 \\
\hline (4) carophyl & 0.15 & 0.15 \\
\hline Na-alginate & 10 & 10 \\
\hline filler & 163.3 & 180.3 \\
\hline
\end{tabular}

$\mathrm{CaD}$, carnivorous animal diet; HeD, herbivorous diet; upper digits for protein content of ingredients (\%). ${ }^{(1)}$ Local products; ${ }^{(2)}$ Profine, Argentina; ${ }^{(3)}$ Gluten y Almidones SA de CV, Mexico; ${ }^{(4)}$ DSM, Nutritional Products, México. 
Table 2. Proximal analysis of the diets.

\begin{tabular}{lcc}
\hline & CaD & HeD \\
\hline Moisture & 4.3 & 7.4 \\
Crude protein & 39.5 & 17.5 \\
Ether extract & 10.0 & 8.7 \\
Nitrogen free extract & 23.0 & 44.5 \\
Ash & 22.8 & 21.9 \\
Fiber & 0 & 0 \\
Gross energy (kJ/g) & 14.2 & 13.5 \\
Lysine & 2.7 & 1.5 \\
Arginine & 2.5 & 1.6 \\
Histidine & 0.8 & 0.6 \\
Theronine & 1.5 & 1.0 \\
Methionine & 1.0 & 0.5 \\
\hline
\end{tabular}

$\mathrm{CaD}$, carnivorus animal diet; HeD, herbivorous diet. Values of amino acids from analyses made by CENCOM SA de CV, Mexico.

Table 3. Zootechnical parameters of the experiments. Each experiment lasting 45 days. Mean values \pm SD.

\begin{tabular}{lllll}
\hline & \multicolumn{2}{c}{ Early juveniles } & \multicolumn{2}{c}{ Late juveniles } \\
& \multicolumn{1}{c}{$\mathrm{CaD}$} & $\mathrm{HeD}$ & $\mathrm{CaD}$ & $\mathrm{HeD}$ \\
\hline Survival (\%) & $73.3 \pm 3.6^{\mathrm{b}}$ & $91.7 \pm 3.2^{\mathrm{a}}$ & $97.7 \pm 5.4^{\mathrm{a}}$ & $94.0 \pm 0.3^{\mathrm{a}}$ \\
$\begin{array}{l}\text { Initial wet weight } \\
\text { (g) }\end{array}$ & $0.004 \pm 0.001$ & $0.004 \pm 0.001$ & $3.08 \pm 0.7$ & $2.07 \pm 0.6$ \\
Final wet weight & $0.21 \pm 0.01^{\mathrm{a}}$ & $0.18 \pm 0.01^{\mathrm{a}}$ & $6.09 \pm 0.09^{\mathrm{a}}$ & $3.3 \pm 0.02^{\mathrm{b}}$ \\
(g) & & & \\
\hline
\end{tabular}

$\mathrm{CaD}$, carnivorous animal diet; HeD, herbivorous diet. Different letters in the superscript indicate significant difference between treatments in each experiment $(p<0.05)$. 
Table 4. Energy partitioning ( $\left.\mathrm{J}_{\text {animal }}{ }^{-1} \mathrm{day}^{-1}\right)$ measured for early and late juveniles. Mean values \pm SD $(n=9)$.

\begin{tabular}{|c|c|c|c|c|}
\hline & \multicolumn{2}{|c|}{ Early juveniles } & \multicolumn{2}{|c|}{ Late juveniles } \\
\hline & $\mathrm{CaD}$ & HeD & $\mathrm{CaD}$ & $\mathrm{HeD}$ \\
\hline $\mathrm{DE}$ & $594.66 \pm 75.9^{a}$ & $639.3 \pm 172.5^{a}$ & $1291.5 \pm 109^{\mathrm{a}}$ & $1002.5 \pm 94.2^{\mathrm{a}}$ \\
\hline UE+ZE & $2.9 \pm 1.2^{\mathrm{a}}$ & $5.4 \pm 2^{\mathrm{a}}$ & $6.50 \pm 0.8^{\mathrm{a}}$ & $4.64 \pm 0.6^{a}$ \\
\hline PANE & $2.25 \pm 0.7^{\mathrm{a}}$ & $0.61 \pm 0.04^{b}$ & $9.7 \pm 1.3^{\mathrm{a}}$ & $10.3 \pm 3^{a}$ \\
\hline $\mathrm{H}_{\mathrm{e}} \mathrm{E}$ & $463 \pm 97.8^{\mathrm{a}}$ & $392 \pm 114^{a}$ & $817.5 \pm 32.7^{\mathrm{a}}$ & $571 . \pm 12.2^{a}$ \\
\hline $\mathrm{H}_{\mathrm{i}} \mathrm{E}$ & $67.1 \pm 14.3^{\mathrm{a}}$ & $164.4 \pm 74^{b}$ & $128.4 \pm 12.1^{\mathrm{a}}$ & $284.8 \pm 7.1^{b}$ \\
\hline $\mathrm{RE}$ & $59.4 \pm 6.6^{a}$ & $76.9 \pm 19^{a}$ & $329.4 \pm 9.0^{\mathrm{a}}$ & $131.8 \pm 8^{b}$ \\
\hline $\begin{array}{c}\text { RE/DE } \\
(\%)\end{array}$ & 10.0 & 12.0 & 25.5 & 13.1 \\
\hline
\end{tabular}

$\mathrm{CaD}$, carnivorous animal diet; HeD, herbivorous diet; $\mathrm{DE}$, digestible energy; UE+ZE, routine nitrogen excretion; PANE, post-alimentary nitrogen excretion; $\mathrm{H}_{\mathrm{e}} \mathrm{E}$ routine respiration; $\mathrm{H}_{\mathrm{i}} \mathrm{E}$ heat increment due feeding; $\mathrm{RE}$, recovered energy obtained from energy content of the carcass multiplied by weight gain per day. Different letters in the superscript indicate significant difference between treatments in each experiment $(p<0.05)$.

Table 5. Values of O:N ratio for early and late starved and fed juveniles.

\begin{tabular}{|c|c|c|c|c|c|c|c|c|}
\hline & \multicolumn{4}{|c|}{ Early juveniles } & \multicolumn{4}{|c|}{ Late juveniles } \\
\hline & \multicolumn{2}{|c|}{ starved } & \multicolumn{2}{|c|}{ fed } & \multicolumn{2}{|c|}{ starved } & \multicolumn{2}{|c|}{ fed } \\
\hline & $\mathrm{CaD}$ & $\mathrm{HeD}$ & $\mathrm{CaD}$ & $\mathrm{HeD}$ & $\mathrm{CaD}$ & $\mathrm{HeD}$ & $\mathrm{CaD}$ & $\mathrm{HeD}$ \\
\hline $\mathrm{O}: \mathrm{N}$ & 177 & \begin{tabular}{|c|}
69 \\
\end{tabular} & 160 & 164 & \begin{tabular}{|l}
98 \\
\end{tabular} & 20 & 34 & 34 \\
\hline $\begin{array}{l}\text { Metabolic } \\
\text { substrate }^{*}\end{array}$ & $\begin{array}{l}\text { cbh + } \\
\text { lipid }\end{array}$ & $\begin{array}{l}\text { prot + } \\
\text { lipid }\end{array}$ & $\begin{array}{l}\text { cbh + } \\
\text { lipid }\end{array}$ & $\begin{array}{l}\text { cbh + } \\
\text { lipid }\end{array}$ & $\begin{array}{l}\text { cbh + } \\
\text { lipid }\end{array}$ & prot & $\begin{array}{l}\text { prot + } \\
\text { lipid }\end{array}$ & $\begin{array}{c}\text { prot + } \\
\text { lipid }\end{array}$ \\
\hline
\end{tabular}

$\mathrm{CaD}$, carnivorous animal diet; HeD, herbivorous diet; cbh, carbohydrates; prot, protein; ${ }^{*}$ ) Range according to Mayzaud and Conover (1988): from 3- 6 protein, between 50-60 a mix of protein and lipids, above this a mix of lipids and carbohydrates. 

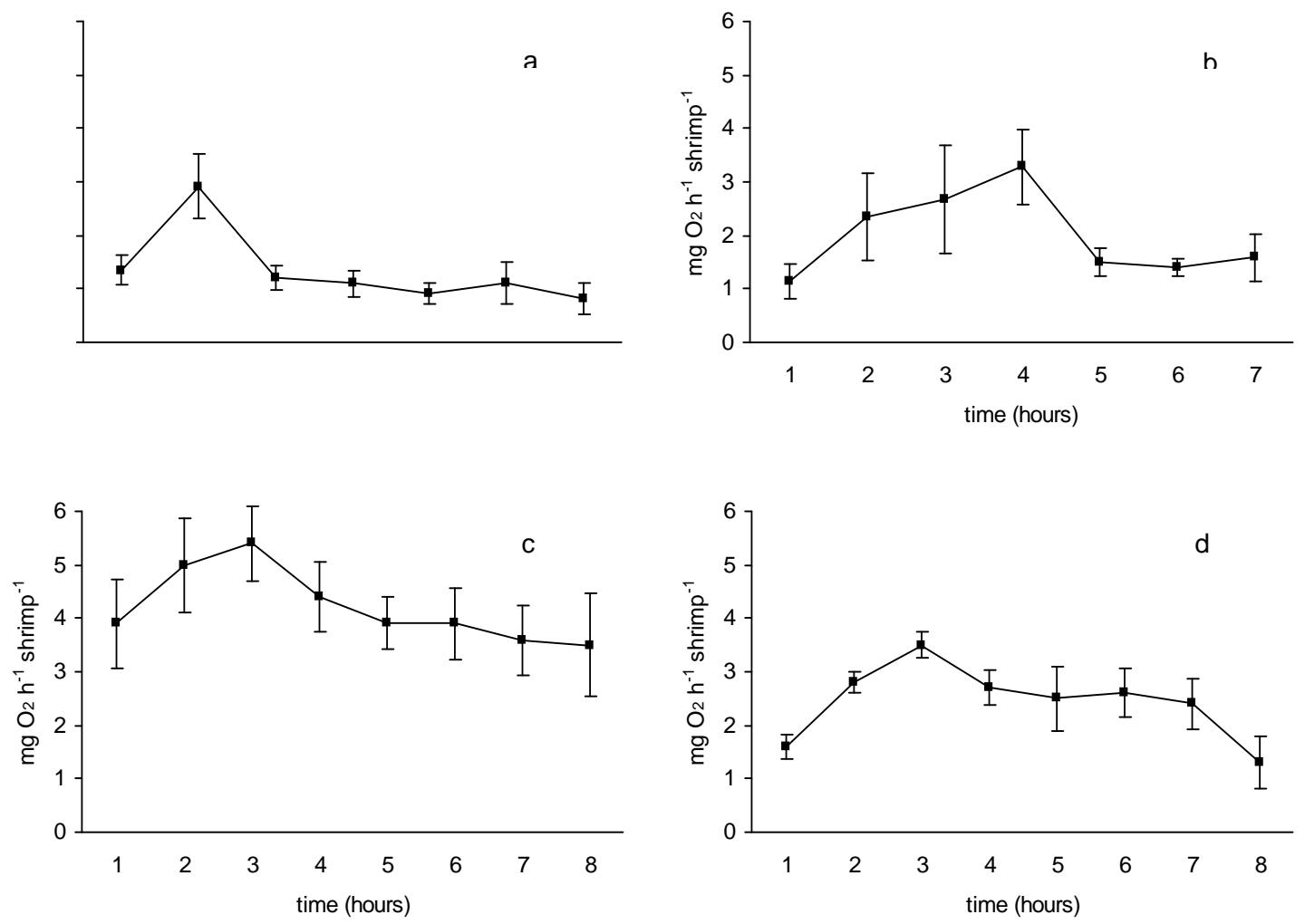

Figure 1. Oxygen consumption (mean $\pm \mathrm{SE}$ ) of $L$. vannamei early juveniles fed control diet (a) or extreme diet (b), and late juveniles fed control diet (c) or extreme diet (d). 

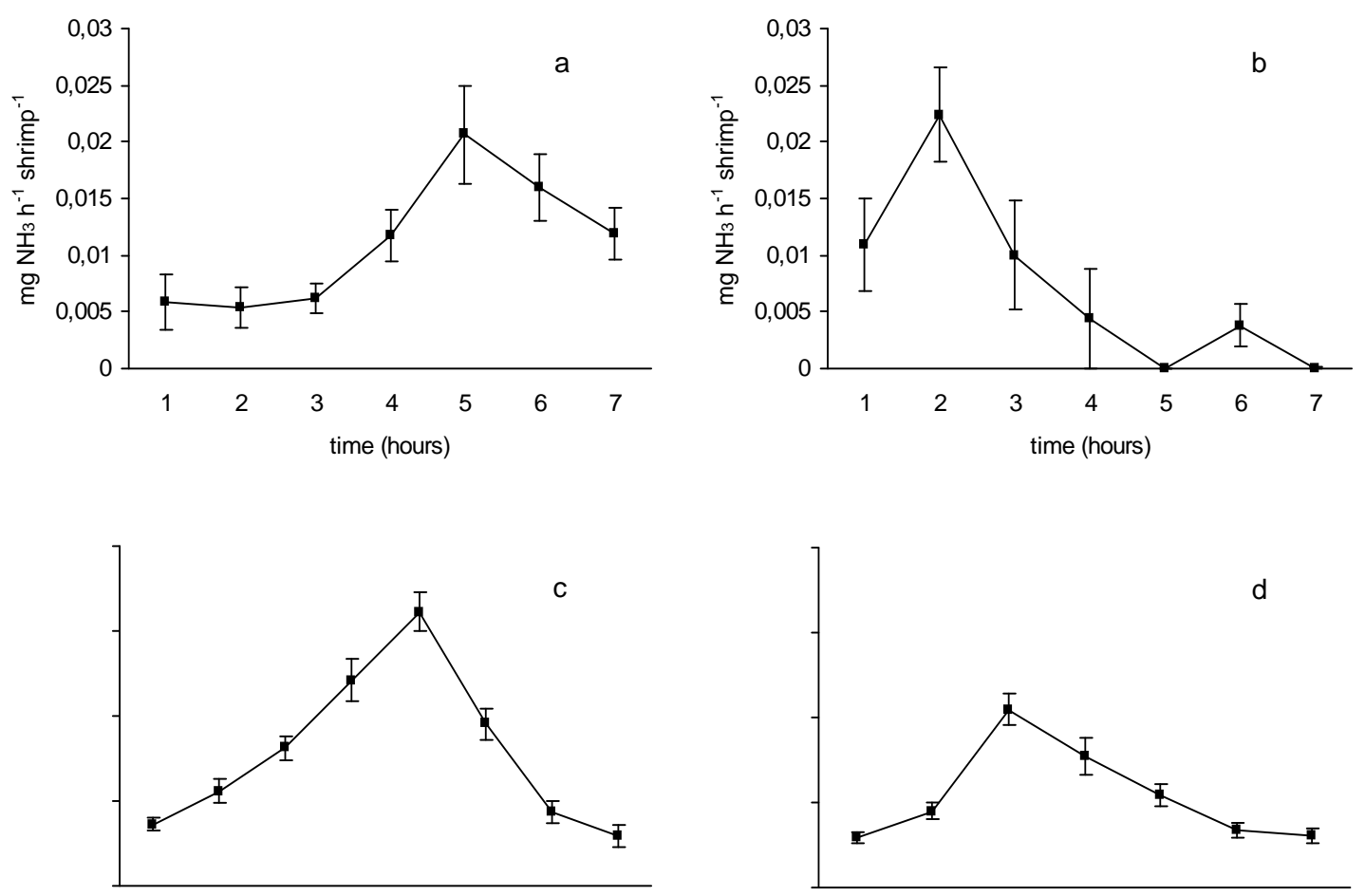

Figure 2. Ammonia excretion (mean $\pm \mathrm{SE}$ ) of $L$. vannamei early juveniles fed control diet (a) or extreme diet (b), and late juveniles fed control diet (c) or extreme diet (d). 